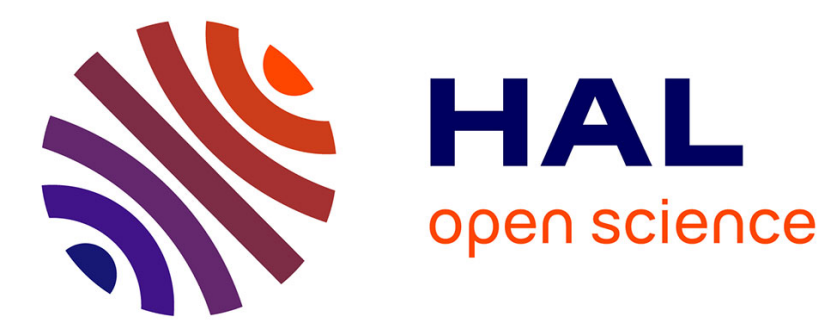

\title{
Hydrothermally stable Pd/SiO2@Zr Core@Shell catalysts for diesel oxidation applications
}

Chih-Han Liu, Junjie Chen, Todd Toops, Jae-Soon Choi, Cyril Thomas, Michael Lance, Eleni Kyriakidou

\section{To cite this version:}

Chih-Han Liu, Junjie Chen, Todd Toops, Jae-Soon Choi, Cyril Thomas, et al.. Hydrothermally stable $\mathrm{Pd} / \mathrm{SiO} 2 @ Z \mathrm{Zr}$ Core@Shell catalysts for diesel oxidation applications. Chemical Engineering Journal, 2021, 425, pp.130637. 10.1016/j.cej.2021.130637 . hal-03343231

\section{HAL Id: hal-03343231 \\ https://hal.science/hal-03343231}

Submitted on 14 Sep 2021

HAL is a multi-disciplinary open access archive for the deposit and dissemination of scientific research documents, whether they are published or not. The documents may come from teaching and research institutions in France or abroad, or from public or private research centers.
L'archive ouverte pluridisciplinaire HAL, est destinée au dépôt et à la diffusion de documents scientifiques de niveau recherche, publiés ou non, émanant des établissements d'enseignement et de recherche français ou étrangers, des laboratoires publics ou privés. 


\title{
Hydrothermally Stable Pd/SiO $@$ @Zr Core@Shell Catalysts for Diesel Oxidation Applications
}

\author{
Chih-Han Liu ${ }^{\mathrm{a},+}$, Junjie Chen ${ }^{\mathrm{a},+}$, Todd J. Toops ${ }^{\mathrm{b}}$, Jae-Soon Choi ${ }^{\mathrm{b}, 1}$, Cyril Thomas ${ }^{\mathrm{c}}$, Michael J. \\ Lance $^{\mathrm{b}}$, and Eleni A. Kyriakidou ${ }^{\mathrm{a},{ }^{*}}$ \\ ${ }^{a}$ Department of Chemical and Biological Engineering, University at Buffalo, The State University of New York, \\ Buffalo, NY 14260, USA \\ ${ }^{b}$ Oak Ridge National Laboratory, Oak Ridge, TN 37831, USA \\ 'Sorbonne Université, CNRS, Laboratoire de Réactivité de Surface (LRS), 4 Place Jussieu, F-75252 Paris, France \\ ${ }^{+}$These authors contributed equally to this work
}

${ }^{1}$ Present address: Catalyst Development Center, Basic Materials and Chemicals R\&D, LG Chem, Daejeon, Korea.

*Corresponding author at: elenikyr@,buffalo.edu (E.A. Kyriakidou)

This manuscript has been authored by UT-Battelle, LLC under Contract No. DE-AC0500OR22725 with the U.S. Department of Energy. The United States Government retains and the publisher, by accepting the article for publication, acknowledges that the United States Government retains a non-exclusive, paid-up, irrevocable, world-wide license to publish or reproduce the published form of this manuscript, or allow others to do so, for United States Government purposes. The Department of Energy will provide public access to these results of federally sponsored research in accordance with the DOE Public Access Plan (http://energy.gov/downloads/doe-public-access-plan). 
Keywords: diesel oxidation catalyst; heterogeneous catalysis; hydrothermal stability; oxidation; core@shell 


\section{Introduction}

Future aftertreatment systems will need to perform efficiently at increasingly low exhaust temperatures [1-3]: this so-called " $150{ }^{\circ} \mathrm{C}$ challenge [4]" (i.e., achieve over $90 \%$ conversion below $150^{\circ} \mathrm{C}$ ) arises from continued improvements in engines efficiency and increasingly strict emission standards. An aftertreatment system normally consists of a diesel oxidation catalyst (DOC) for the oxidation of $\mathrm{CO}$ and hydrocarbons (HCs), a diesel particulate filter for the oxidation of particulate matter, and a selective catalytic reduction $(\mathrm{SCR})$ catalyst for the reduction of $\mathrm{NO}_{\mathrm{x}}$ to $\mathrm{N}_{2}$ [5-7]. A DOC is required to survive hydrothermal aging at $800{ }^{\circ} \mathrm{C} / 50 \mathrm{~h}$ under a feed of $10 \%$ $\mathrm{O}_{2}, 5 \% \mathrm{H}_{2} \mathrm{O}, 5 \% \mathrm{CO}_{2}$ that represents the in-use durability of a catalyst based on the low temperature aftertreatment protocol defined by U.S. DRIVE [8-10]. Under this severe aging condition, active metals tend to sinter resulting in loss of their catalytic activity [11-13]. Enhancing the metal-support interaction has shown to prevent active metal sintering [14-16]. For example, Kim et al. pretreated $\mathrm{Pt}-\mathrm{TiO}_{2}$ under a $\mathrm{H}_{2}$ atmosphere at various reduction temperatures, and the results showed that pretreatment at $600{ }^{\circ} \mathrm{C}$ led to a higher $\mathrm{CO}$ conversion (100\%) compared to a lower CO conversion (10\%) achieved at room temperature when the catalyst was pretreated at 300 ${ }^{\circ} \mathrm{C}[16]$. This behavior was attributed to the strong metal $(\mathrm{Pt})$-support $\left(\mathrm{TiO}_{2}\right)$ interaction $(\mathrm{SMSI})$ occurring after pretreatment at temperatures $>500{ }^{\circ} \mathrm{C}$, evidenced by the formation of smaller $\mathrm{Pt}$ particles (2.2-4.4 nm) compared to larger Pt particles (4.7-5.9 nm) formed after pretreatments at temperatures $<500{ }^{\circ} \mathrm{C} . \mathrm{ZrO}_{2}$ was reported to have SMSI with platinum group metals (PGMs), commonly used in DOCs [17-19]. SMSI between PGMs and $\mathrm{ZrO}_{2}$ lead to high PGM dispersion and thus an improved DOC activity. Specifically, the $\mathrm{T}_{50,90}$ 's (temperature of 50 and $90 \%$ conversion) over $1 \mathrm{wt} . \% \mathrm{Pd} / \mathrm{ZrO}_{2}$ were as low as $160,180{ }^{\circ} \mathrm{C}$ for $\mathrm{CO}$ and $180,195{ }^{\circ} \mathrm{C}$ for propylene $\left(\mathrm{C}_{3} \mathrm{H}_{6}\right)$, respectively [20]. However, $\mathrm{Pd} / \mathrm{ZrO}_{2}$ suffers from a severe surface area loss from $93 \mathrm{~m}^{2} / \mathrm{g}$ 
$\left(500{ }^{\circ} \mathrm{C} / 2 \mathrm{~h}, 10 \% \mathrm{H}_{2} / \mathrm{Ar}\right.$ ) to $24 \mathrm{~m}^{2} / \mathrm{g}$ (hydrothermal aging, $800{ }^{\circ} \mathrm{C} / 16 \mathrm{~h}, 10 \% \mathrm{O}_{2}, 5 \% \mathrm{H}_{2} \mathrm{O} / \mathrm{Ar}$ ) due to the growth of the mean $\mathrm{ZrO}_{2}$ crystallite size [20]. The $\mathrm{ZrO}_{2}$ surface area loss can be prevented by incorporating oxides with higher crystallization temperature than $\mathrm{ZrO}_{2}\left(\sim 150^{\circ} \mathrm{C}\right.$ [21]), e.g. $\mathrm{Al}_{2} \mathrm{O}_{3}\left(850-900{ }^{\circ} \mathrm{C}\right.$ [22]) or $\mathrm{SiO}_{2}\left(1000-1400{ }^{\circ} \mathrm{C}[23,24]\right)$ [25]. Specifically, $\mathrm{Al}_{2} \mathrm{O}_{3}-\mathrm{ZrO}_{2}$ and $\mathrm{ZrO}_{2}-$ $\mathrm{SiO}_{2}$ have a crystallization temperature of 700 and $800{ }^{\circ} \mathrm{C}$, respectively $[21,26]$. Thus, $\mathrm{ZrO}_{2}-\mathrm{SiO}_{2}$ mixed oxide supports were utilized considering the exhaust temperature $\left(500-700{ }^{\circ} \mathrm{C}\right)$ of diesel engines at $100 \%$ load $[20,27,28]$. Specifically, Kim et al. showed that hydrothermally aged (HTA) $\left(800{ }^{\circ} \mathrm{C} / 16 \mathrm{~h}\right) \mathrm{Pd} / \mathrm{ZrO}_{2}-\mathrm{SiO}_{2}$ had a $\mathrm{T}_{50}$ and $\mathrm{T}_{90}$ for $\mathrm{CO}$ at 280 and $320{ }^{\circ} \mathrm{C}$ and for $\mathrm{C}_{3} \mathrm{H}_{6}$ at 307 and $332{ }^{\circ} \mathrm{C}$, respectively [20]. Furthermore, incorporation of $\mathrm{SiO}_{2}$, as an acidic support, is known to improve the sulfur tolerance of the catalyst compared to bare $\mathrm{ZrO}_{2}$ [20]. However, uncontrolled synthesis of $\mathrm{ZrO}_{2}-\mathrm{SiO}_{2}$ by a sol-gel method resulted in segregation of $\mathrm{SiO}_{2}$ and $\mathrm{ZrO}_{2}$, leading to formation of large $\mathrm{Pd}$ particles on exposed $\mathrm{SiO}_{2}$ surfaces due to weak $\mathrm{Pd}-\mathrm{SiO}_{2}$ interaction. Specifically, the $\mathrm{Pd}$ particle size over $\mathrm{Pd} / \mathrm{ZrO} 2, \mathrm{Pd} / \mathrm{ZrO}_{2}-\mathrm{SiO}_{2}, \mathrm{Pd} / \mathrm{SiO}_{2}$ increased from $1.1 \mathrm{~nm}$ to $1.9 \mathrm{~nm}$ to $4.1 \mathrm{~nm}$, respectively [20]. Therefore, a complete coverage of $\mathrm{SiO}_{2}$ by a $\mathrm{Zr}$ based shell is required to prevent $\mathrm{Pd}$ deposition on $\mathrm{SiO}_{2}$ and thus enhance the diesel oxidation performance of $\mathrm{Pd} / \mathrm{ZrO}_{2}-\mathrm{SiO}_{2}$ catalysts.

Herein, $\mathrm{SiO}_{2}$ (core)@ $\mathrm{Zr}$ (shell) supports were synthesized, where $\mathrm{SiO}_{2}$ spheres were covered by a Zr-based shell. This was achieved by a hard template method as reported previously (Fig. 1) [3], where the $\mathrm{SiO}_{2}$ core acted as a scaffold for the growth of the $\mathrm{Zr}$-based shell layer. Pd was deposited on the $\mathrm{SiO}_{2} @ \mathrm{Zr}$ support by wet-impregnation resulting to 1,2 and 4 wt.\% $\mathrm{Pd} / \mathrm{SiO}_{2} @ \mathrm{Zr}$ catalysts that were evaluated for their diesel oxidation activity and hydrothermal stability.

\section{Experimental procedure}


Reagents and materials, and characterizations are listed in the Supplementary material.

\subsection{Catalysts preparation}

The $\mathrm{SiO}_{2} @ \mathrm{Zr}$ core@shell support was synthesized, with some modifications, as reported previously [3]. The synthesis schematic is shown in Fig. 1. Briefly, monodisperse silica spheres were prepared following the Stöber process [29]. The $\mathrm{SiO}_{2}$ spheres formed were dispersed in 100 $\mathrm{g}$ of ethanol and kept at $30{ }^{\circ} \mathrm{C}$. Afterwards, $0.5 \mathrm{~mL}$ of Brij30 solution was added to the $\mathrm{SiO}_{2}$ suspension and kept stirring for $1 \mathrm{~h}$. Then, $1.8 \mathrm{~mL} \operatorname{Zr}(\mathrm{BuO})_{4}$ was added and the solution was stirred overnight at $30{ }^{\circ} \mathrm{C}$. The liquid phase of the colloid was then exchanged for $100 \mathrm{~mL}$ DI water (4 times) and aged at room temperature for 3 days. Finally, the $\mathrm{SiO}_{2} @ \mathrm{Zr}$ spheres were collected after centrifugation followed by drying at $110^{\circ} \mathrm{C}$ overnight and calcination at $500{ }^{\circ} \mathrm{C}$ for $2 \mathrm{~h}\left(10{ }^{\circ} \mathrm{C} / \mathrm{min}\right)$.

The resulting $\mathrm{SiO}_{2} @ \mathrm{Zr}$ support was impregnated with 2.8, 5.6, $11.4 \mathrm{~mL} \mathrm{Pd}\left(\mathrm{NH}_{3}\right)_{4}\left(\mathrm{NO}_{3}\right)_{2}$ solution $(0.0344 \mathrm{M})$ by wet-impregnation where the $\mathrm{pH}$ of the slurry was adjusted to 4 with $0.1 \mathrm{M}$ $\mathrm{HNO}_{3}$, leading to $\mathrm{Pd}$ loadings of 1,2 , and 4 wt.\%. The liquid phase of the slurry was then evaporated at room temperature. After the impregnation, the catalyst was dried at $110{ }^{\circ} \mathrm{C}$ in air and calcined at $500{ }^{\circ} \mathrm{C}$ for $2 \mathrm{~h}$.

\subsection{Catalyst evaluation}

The performance of the as-synthesized catalysts was evaluated in a customized fixed-bed U-shaped quartz reactor (I.D. $=8 \mathrm{~mm}$ ) as reported previously [30]. The reactor was placed in a cylindrical furnace surrounded by quartz wool to eliminate heat gradients. A K-type thermocouple was attached outside the reactor, close to the top of the catalyst bed, to allow the PID temperature controller control the furnace temperature. Catalyst powders were pressed and sieved and a final pellet size range between 250 to $500 \mu \mathrm{m}$ was used to avoid pressure effects during the reaction. 
$100 \mathrm{mg}$ of catalyst was loaded in the reactor stabilized by two loosely packed quartz wool plugs. Another K-type thermocouple was inserted through the reactor U-tube to the upper quartz wool plug for measuring the inlet gas temperature.

The catalysts were first degreened (DG) $\left(700{ }^{\circ} \mathrm{C} / 4 \mathrm{~h}\right)$ under feed gas composition of $10 \%$ $\mathrm{O}_{2}, 5 \% \mathrm{H}_{2} \mathrm{O}, 5 \% \mathrm{CO}_{2} / \mathrm{Ar}$. Before evaluation, the catalysts were pretreated at $600{ }^{\circ} \mathrm{C}$ with $12 \% \mathrm{O}_{2}$, $6 \% \mathrm{H}_{2} \mathrm{O}, 6 \% \mathrm{CO}_{2} / \mathrm{Ar}$ for $20 \mathrm{~min}$. Diesel oxidation evaluation experiments were performed using the low temperature combustion of diesel (LTC-D) gas composition defined by U.S. DRIVE (Table S1) [8]. The total flow rate was $333 \mathrm{sccm}$ that corresponds to a gas hourly space velocity (GHSV) of 113,000 h ${ }^{-1} . \mathrm{CO}_{2}, \mathrm{O}_{2}, \mathrm{H}_{2}, \mathrm{CO}, \mathrm{NO}, \mathrm{C}_{2} \mathrm{H}_{4}, \mathrm{C}_{3} \mathrm{H}_{6}, \mathrm{C}_{3} \mathrm{H}_{8}$ and $\mathrm{Ar}$ (UHP, Airgas) were regulated by a set of MKS mass flow controllers. Water was supplied by a D-series pump (Teledyne Isco), evaporated to steam in a tube furnace $\left(200^{\circ} \mathrm{C}\right)$ and carried by $\mathrm{Ar}$ to the reactor. Light-off tests were conducted from 100 to $500{ }^{\circ} \mathrm{C}$ at a heating rate of $2{ }^{\circ} \mathrm{C} / \mathrm{min}$. The effluent gas concentrations were analyzed by an MKS MultiGas 2030 FTIR gas analyzer with a gas cell at 191 ${ }^{\circ} \mathrm{C}$. The reactor exhaust was diluted with $667 \mathrm{sccm}$ Ar to reduce the response time of the gas analyzer. To avoid water condensation, all the gas lines were heated to $170{ }^{\circ} \mathrm{C}$. Hydrothermal aging (HTA) treatment $\left(800{ }^{\circ} \mathrm{C} / 10 \mathrm{~h}\right)$ was conducted under feed gas composition of $10 \% \mathrm{O}_{2}, 5 \%$ $\mathrm{H}_{2} \mathrm{O}, 5 \% \mathrm{CO}_{2} / \mathrm{Ar}$. Pretreatment and evaluation of the HTA catalysts were performed under the same conditions as the DG catalysts.

\section{Results and Discussion}

The high-angle annular dark-field scanning transmission electron microscopy (HAADFSTEM) images and energy dispersive X-ray spectroscopy (EDS) elemental maps of fresh (calcined at $\left.500{ }^{\circ} \mathrm{C} / 2 \mathrm{~h}\right) 1,2$ and 4 wt.\% $\mathrm{Pd} / \mathrm{SiO}_{2} @ \mathrm{Zr}$ catalysts are shown in Fig. 2. Moreover, a 3D tomography video of 1 wt.\% $\mathrm{Pd} / \mathrm{SiO}_{2} @ \mathrm{Zr}$ is shown (Video $\mathrm{S} 1$ ). The 3D tomography suggests the 
complete coverage of $\mathrm{SiO}_{2}$ core by $\mathrm{Zr}$-based shell with Pd dispersed on the surface. A spherical structure was confirmed for all studied catalysts (Fig. 2). The EDS elemental maps of Si in Fig. 2a.2, $2 \mathrm{~b} .2$ and $2 \mathrm{c} .2$ reveal the successful synthesis of nano-spherical $\mathrm{SiO}_{2}$ (diameter of about 150 $\mathrm{nm}$ ) as a support core. The higher density Zr presented as a shell layer (thickness: $\sim 8.4 \mathrm{~nm}$ ) (Fig. 2a.3, 2b.3 and 2c.3) indicates the successful deposition of $\mathrm{Zr}$ species on the $\mathrm{SiO}_{2}$ core. Palladium is well-dispersed over 1 wt.\% Pd/SiO $@$ @ $\mathrm{Zr}$ (Fig. 2a.4). However, as Pd loading increased to 2 (Fig. 2b.4) and 4 wt.\% (Fig. 2c.4), larger Pd clusters ( $\sim 5$ and $7 \mathrm{~nm}$, respectively) can be observed, possibly due to Pd sintering.

Fig. S1 shows the X-ray diffraction (XRD) patterns of fresh $\mathrm{SiO}_{2} @ \mathrm{Z}$ Zr, fresh and HTA (800 $\left.{ }^{\circ} \mathrm{C} / 10 \mathrm{~h}, 10 \% \mathrm{O}_{2}, 5 \% \mathrm{H}_{2} \mathrm{O}, 5 \% \mathrm{CO}_{2} / \mathrm{Ar}\right) 1$ wt. $\% \mathrm{Pd} / \mathrm{SiO}_{2} @ \mathrm{Zr}$. All samples display only one broad peak centered at $\sim 23^{\circ}$, assigned to $\mathrm{SiO}_{2}$ [31]. No peaks were detected for $\mathrm{ZrO}_{2}$ over all analyzed samples, suggesting that the majority of $\mathrm{Zr}$ in $\mathrm{SiO}_{2} @ \mathrm{Zr}$ is not present in a $\mathrm{ZrO}_{2}$ crystalline phase (monoclinic, tetragonal, cube). Moreover, presence of amorphous $\mathrm{ZrO}_{2}$ is excluded since the samples analyzed by XRD are either fresh (calcined at $500{ }^{\circ} \mathrm{C}$ ) or $\mathrm{HTA}\left(\right.$ exposed to $800{ }^{\circ} \mathrm{C} / 10 \mathrm{~h}$ ) and amorphous $\mathrm{ZrO}_{2}$ can readily crystallize at $\mathrm{T}>300{ }^{\circ} \mathrm{C}$ [32]. Furthermore, no metallic $\mathrm{Pd}$ or PdO peaks were observed over fresh and HTA 1 wt.\% Pd/SiO 2 @ Zr, which might be due to the low loading and the dispersed nature of Pd (Fig. 2a.4).

The surface properties (Brunauer-Emmett-Teller (BET) surface areas and Barrett-JoynerHalenda (BJH) pore volumes) of $\mathrm{SiO}_{2}$ core, $\mathrm{SiO}_{2} @ \mathrm{Zr}$, and 1 wt.\% Pd/SiO $2 @ Z \mathrm{Zr}$ are summarized in Table 1. The surface area of fresh $\mathrm{SiO}_{2}$ core was as low as $2.3 \mathrm{~m}^{2} / \mathrm{g}$. Fresh $\mathrm{SiO}_{2} @ \mathrm{Zr}$ and 1 wt.\%Pd/SiO $@$ @ Zr had improved surface areas of 226.7 and 207.1 m²/g, respectively. Considering the low surface area of $\mathrm{SiO}_{2}$ core, the improved surface areas of $\mathrm{SiO}_{2} @ \mathrm{Zr}$ and 1 wt.\% Pd/SiO $2 @ \mathrm{Zr}$ can be attributed to the Zr-based shell. Furthermore, the surface area loss after HTA was greater 
over 1 wt.\% Pd/ZrO (fresh: $93 \mathrm{~m}^{2} / \mathrm{g}$, HTA (16 h): 24 m²/g) [20] than 1 wt.\% Pd/SiO $@$ @Zr (fresh: $226.7 \mathrm{~m}^{2} / \mathrm{g}$, HTA $\left.(16 \mathrm{~h}): 112 \mathrm{~m}^{2} / \mathrm{g}\right)$. The surface area of 1 wt.\% Pd/SiO $/ \mathrm{Zr}$ after $10 \mathrm{~h}$ of HTA was $104 \mathrm{~m}^{2} / \mathrm{g}$ and it remained the same when the HTA time was extended to $16 \mathrm{~h}\left(112 \mathrm{~m}^{2} / \mathrm{g}\right)$. This observation suggests that the surface area of $\mathrm{Pd} / \mathrm{SiO}_{2} @ \mathrm{Zr}$ does not change after HTA for $10 \mathrm{~h}$. Moreover, the surface area of $\mathrm{Pd} / \mathrm{SiO}_{2} @ \mathrm{Zr}$ is 4.5 times greater than the one of $\mathrm{Pd} / \mathrm{ZrO}_{2}$ after $16 \mathrm{~h}$ of HTA. The significant surface area loss of 1 wt. $\% \mathrm{Pd} / \mathrm{ZrO}_{2}$ when exposed to elevated temperatures was attributed to the grain growth of crystalline $\mathrm{ZrO}_{2}$ [33]. Therefore, the high surface area of $\mathrm{SiO}_{2} @ \mathrm{Zr}$ and 1 wt.\% Pd/SiO crystalline nature of the Zr-based shell (see XRD data (Fig. S1)). The $\mathrm{N}_{2}$ adsorption-desorption isotherms of fresh and HTA 1 wt.\% Pd/SiO $2 @ \mathrm{Zr}$ are shown in Fig. S2. Both samples have a type IV isotherm, characteristic of mesoporous materials [34].

Fig. 3 shows the catalytic evaluation results of degreened (DG) 1wt.\% Pd/SiO $/ \mathrm{S}_{2} \mathrm{Zr} .1$ wt.\% $\%$ d $/ \mathrm{SiO}_{2} @ \mathrm{Zr}$ can achieve 50 and 90\% conversions at 168 and $178{ }^{\circ} \mathrm{C}$ for $\mathrm{CO}$ and 228 and $372{ }^{\circ} \mathrm{C}$ for total HCs (THCs), respectively (Fig. 3a). Moreover, 1 wt.\% Pd/SiO $/ \mathrm{Zr}$ can reach 50 and $90 \%$ conversions at 245 and $362{ }^{\circ} \mathrm{C}$ for $\mathrm{C}_{2} \mathrm{H}_{4}$ and at 192 and $216{ }^{\circ} \mathrm{C}$ for $\mathrm{C}_{3} \mathrm{H}_{6}$, respectively (Fig. 3b). $\mathrm{C}_{3} \mathrm{H}_{8}$ was converted at a higher temperature $\left(\mathrm{T}_{50}=376{ }^{\circ} \mathrm{C}, \mathrm{T}_{90}=428{ }^{\circ} \mathrm{C}\right)$ compared to $\mathrm{C}_{2} \mathrm{H}_{4}$ and $\mathrm{C}_{3} \mathrm{H}_{6}$, attributed to its stable $\mathrm{C}-\mathrm{H}$ bonds [35]. The negative conversion of $\mathrm{C}_{3} \mathrm{H}_{8}$ observed between 180 and $340{ }^{\circ} \mathrm{C}$ (Fig. 3b) can be attributed to the desorption of $\mathrm{C}_{3} \mathrm{H}_{8}$ from $\mathrm{PdO}$ [36]. The inflection in $\mathrm{CO}$ conversion at $190{ }^{\circ} \mathrm{C}$ (Fig. 3a) can be attributed to competition of $\mathrm{CO}$ and $\mathrm{HCs}$ for active sites and mass transfer limitations [37]. Moreover, the inflection observed in $\mathrm{C}_{2} \mathrm{H}_{4}$ conversion (Fig. 3b) can be attributed to the adsorption of intermediates formed during $\mathrm{C}_{2} \mathrm{H}_{4}$ oxidation on $\mathrm{Pd}$ active sites (discussed later). These intermediate species can inhibit $\mathrm{C}_{2} \mathrm{H}_{4}$ adsorption and its further oxidation. Fig. $3 \mathrm{c}$ shows the concentrations of $\mathrm{NO}, \mathrm{NO}_{2}$ and $\mathrm{N}_{2} \mathrm{O}$ and 
their total concentration $\left(=[\mathrm{NO}]+\left[\mathrm{NO}_{2}\right]+2\left[\mathrm{~N}_{2} \mathrm{O}\right]\right)$ during the evaluation of DG 1 wt.\% $\mathrm{Pd} / \mathrm{SiO}_{2} @ \mathrm{Zr}$. The total concentration of $\mathrm{NO}, \mathrm{NO}_{2}$, and $\mathrm{N}_{2} \mathrm{O}$ indicates that most $\mathrm{N}$-containing species were in the form of $\mathrm{NO}, \mathrm{NO}_{2}$, and $\mathrm{N}_{2} \mathrm{O}$. The small negative peak observed at $165^{\circ} \mathrm{C}$ can be attributed to $\mathrm{N}_{2}$ formation (not detectable by the MKS IR). There are three NO consumption peaks at 165,206 and $471{ }^{\circ} \mathrm{C}$. NO consumed at 165 and $206{ }^{\circ} \mathrm{C}$ was converted to $\mathrm{N}_{2}$ and $\mathrm{N}_{2} \mathrm{O}$, respectively, suggesting that a HC-SCR reaction took place [38]. The third broad NO consumption peak at temperature $\sim 471{ }^{\circ} \mathrm{C}$ can be attributed to the catalytic NO oxidation over Pd [39] and homogeneous (gas phase) NO oxidation [30].

A hydrothermal aging treatment $\left(800^{\circ} \mathrm{C} / 10 \mathrm{~h}\right)$ was conducted to verify the durability of 1

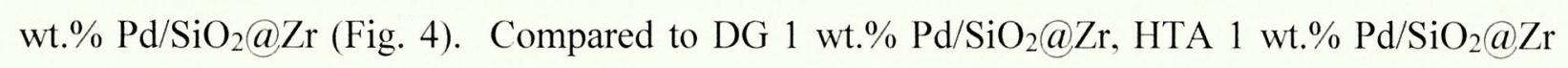
showed similar $\mathrm{T}_{50}\left(168^{\circ} \mathrm{C}\right)$ and $\mathrm{T}_{90}\left(178^{\circ} \mathrm{C}\right)$ for $\mathrm{CO}$, while minor deactivation was observed for HC oxidation. Specifically, the $\mathrm{T}_{50}\left(207^{\circ} \mathrm{C}\right)$ and $\mathrm{T}_{90}\left(372^{\circ} \mathrm{C}\right)$ for THCs was increased by only 21 and $9{ }^{\circ} \mathrm{C}$, respectively, after hydrothermal aging of 1 wt.\% $\mathrm{Pd} / \mathrm{SiO}_{2} @ \mathrm{ZrO}_{2}$. The ability of 1 wt.\% $\mathrm{Pd} / \mathrm{SiO}_{2} @ \mathrm{Zr}$ to achieve a similar performance under DG and HTA conditions highlights the hydrothermal stability of the catalyst. Similarly, the negative conversion of $\mathrm{C}_{3} \mathrm{H}_{8}$ observed between 180 and $340{ }^{\circ} \mathrm{C}$ (Fig. 4b) can be attributed to the desorption of $\mathrm{C}_{3} \mathrm{H}_{8}$ from $\mathrm{PdO}$ [36]. Formaldehyde $\left(\mathrm{CH}_{2} \mathrm{O}\right)$ was formed at the same temperature range that the inflection in $\mathrm{C}_{2} \mathrm{H}_{4}$ conversion was observed (Figs. S3a, 4b). The inflection in $\mathrm{C}_{2} \mathrm{H}_{4}$ conversion was also observed when $\mathrm{CO}, \mathrm{NO}, \mathrm{C}_{3} \mathrm{H}_{6}$ and $\mathrm{C}_{3} \mathrm{H}_{8}$ were removed from the reactor feed (1667 ppm $\mathrm{C}_{2} \mathrm{H}_{4}\left(\mathrm{C}_{1}\right.$ basis), $6 \% \mathrm{CO}_{2}, 6 \% \mathrm{H}_{2} \mathrm{O}, 12 \% \mathrm{O}_{2}$, and $400 \mathrm{ppm} \mathrm{H}_{2}$ ) (Fig. S3b). This observation indicates that intermediates (e.g. $\mathrm{CH}_{2} \mathrm{O}, \mathrm{CO}$ ) formed during $\mathrm{C}_{2} \mathrm{H}_{4}$ oxidation can be adsorbed on the $\mathrm{Pd}$ active sites. The adsorbed intermediates can inhibit $\mathrm{C}_{2} \mathrm{H}_{4}$ adsorption and thus its further oxidation. Similar NO conversion pattern was observed over both DG and HTA 1 wt.\% Pd/SiO $@$ ar (Fig. 
4c). The decrease in the total concertation of $\mathrm{NO}, \mathrm{NO}_{2}$, and $\mathrm{N}_{2} \mathrm{O}$ can be attributed to HC-SCR reactions [38], as discussed previously.

The effect of Pd loading was investigated by comparing the catalytic performance of 1,2 , and 4 wt.\% Pd/SiO $2 @ Z r$ (Fig. 5). The CO T50/T90's were similar at 168/178, 168/179 and 158/172 ${ }^{\circ} \mathrm{C}$ over DG 1, 2 and 4 wt.\% Pd/SiO $/ \mathrm{SO}_{2} \mathrm{Zr}$, respectively (Fig. 5a). However, the THC $\mathrm{T}_{50,90}$ 's decreased as Pd loading increased. Specifically, the THC $\mathrm{T}_{50} / \mathrm{T}_{90}$ 's decreased from $228 / 372{ }^{\circ} \mathrm{C}$ to $211 / 355^{\circ} \mathrm{C}$ to $191 / 316^{\circ} \mathrm{C}$ over DG 1,2 and 4 wt.\% Pd/SiO 2 @ $\mathrm{Zr}$, respectively. After hydrothermal aging the $\mathrm{T}_{50} / \mathrm{T}_{90}$ 's for $\mathrm{CO}$ slightly decreased from $165 / 178$ to $163 / 176$ to $163 / 172{ }^{\circ} \mathrm{C}$ with increasing Pd loading from 1 to 2 to 4 wt.\% (Fig. 5b). Similarly, the T $_{50,90}$ 's for THCs decreased with increasing Pd loading from 1 to 2 to 4 wt. $\%$ as follows: $207 / 381{ }^{\circ} \mathrm{C}$ to $202 / 343{ }^{\circ} \mathrm{C}$ to $190 / 325$ ${ }^{\circ} \mathrm{C}$, respectively.

Fourier transform infrared (FT-IR) spectra were collected over $\mathrm{SiO}_{2}$ spheres and $\mathrm{SiO}_{2} @ \mathrm{Zr}$ supports to investigate the support composition and thus the origin of the Pd/SiO $@$ ar thermal stability (Fig. S4). Two peaks at 1101 and $802 \mathrm{~cm}^{-1}$ were detected over both $\mathrm{SiO}_{2}$ spheres and $\mathrm{SiO}_{2} @ \mathrm{Zr}$ supports, attributed to Si-O-Si bonds [40]. The decrease observed in the transmittance at $965 \mathrm{~cm}^{-1}$ over $\mathrm{SiO}_{2} @ \mathrm{Zr}$ suggested the formation of $\mathrm{Si}-\mathrm{O}-\mathrm{Zr}$ bonds after $\mathrm{Zr}$ coating [41]. Moreover, Schüth et al. reported that the bulk and surface $\mathrm{Zr} / \mathrm{Si}$ molar ratio of the core@shell support was 0.2 and 1 , respectively [42]. Si-O-Zr bond formation can hinder the crystallization of the $\mathrm{Zr}$-based shell [43]. Therefore, the improved hydrothermal stability of $\mathrm{Pd} / \mathrm{SiO}_{2} @ \mathrm{Zr}$ can be attributed to the presence of Si-O-Zr.

$\mathrm{NO}_{\mathrm{x}}$-TPD provided an additional indication of the presence of $\mathrm{Si}-\mathrm{O}-\mathrm{Zr}$ bonds over $\mathrm{SiO}_{2} @ \mathrm{Zr}$ supports. Law et al. showed that there is a linear relationship between $\mathrm{NO}_{\mathrm{x}}$ uptake and the accessible $\mathrm{ZrO}_{2}$ surface area $[44,45]$. Thus, $\mathrm{NO}_{\mathrm{x}}-\mathrm{TPD}$ was conducted to titrate the accessible 
surface area of $\mathrm{ZrO}_{2}$ in $\mathrm{SiO}_{2} @ \mathrm{Zr}$. The amount of desorbed $\mathrm{NO}_{\mathrm{x}}$ was calculated to be $0.17 \mu \mathrm{mol}$ $\mathrm{NO}_{\mathrm{x}} / \mathrm{m}^{2} \mathrm{SiO}_{2}$ @ Zr (Fig. 6), which is much lower than that of bare $\mathrm{ZrO}_{2}\left(5.8 \mu \mathrm{mol} \mathrm{NO}_{\mathrm{x}} / \mathrm{m}^{2} \mathrm{ZrO}_{2}\right)[44$, 45]. This result indicates that bare $\mathrm{ZrO}_{2}$ presence on the $\mathrm{SiO}_{2} @ \mathrm{Zr}$ surface is minimal. This observation is consistent with the $\mathrm{SiO}_{2} @ \mathrm{Zr}$ XRD data (Fig. S1) where crystallized $\mathrm{ZrO}_{2}$ was not detected. Moreover, $\mathrm{SiO}_{2} @ \mathrm{Zr}$ (Fig. 6) and $\mathrm{ZrSiO}_{4}$ (Fig. S5), that contains Si-O-Zr bonds, showed similar $\mathrm{NO}_{\mathrm{x}}$ desorption temperatures and $\mathrm{NO}_{\mathrm{x}}$ update $\left(0.43 \mu \mathrm{mol} \mathrm{NO} / \mathrm{m}^{2} \mathrm{ZrSiO}_{4}\right)$ indicating that the samples have a similar surface composition [46]. Therefore, the low $\mathrm{NO}_{\mathrm{x}}$ uptake over $\mathrm{SiO}_{2} @ \mathrm{Zr}$ can be attributed to the formation of Si-O-Zr bonds on its surface.

\section{Conclusions}

In this work, a series of hydrothermal stable Pd-based DOCs on a novel $\mathrm{SiO}_{2} @ \mathrm{Zr}$ support were synthesized. Degreened 1 wt.\% Pd/SiO $2 @ Z$ Zr was able to reach 90\% CO and THC conversion at 178 and $372{ }^{\circ} \mathrm{C}$, respectively (feed: $6 \% \mathrm{CO}_{2}, 12 \% \mathrm{O}_{2}, 6 \% \mathrm{H}_{2} \mathrm{O}, 400 \mathrm{ppm} \mathrm{H}_{2}, 2000$ ppm CO, 100 ppm NO, 1667 ppm $\mathrm{C}_{2} \mathrm{H}_{4}, 1000$ ppm $\mathrm{C}_{3} \mathrm{H}_{6}, 333$ ppm $\mathrm{C}_{3} \mathrm{H}_{8} ; \mathrm{HC}$ in $\mathrm{C}_{1}$ basis and GHSV $=113,000 \mathrm{~h}^{-1}$ ). Only a minor decrease in the THC conversion was observed after hydrothermal aging at $800{ }^{\circ} \mathrm{C}$ for $10 \mathrm{~h}$ (HTA). As the Pd loading increased from 1 to 2 to 4 wt. $\%$, the T90's for THCs decreased from 372 to 346 to $316^{\circ} \mathrm{C}$, respectively. A similar trend was observed for $\mathrm{Pd} / \mathrm{SiO}_{2} @ \mathrm{Zr}$ after HTA, where the THC T90's decreased from 381 to 343 to $325{ }^{\circ} \mathrm{C}$ with increasing $\mathrm{Pd}$ loading from 1 to 2 to 4 wt.\% Pd/SiO $@$ @zr. The high surface area of $\mathrm{Pd} / \mathrm{SiO}_{2} @ \mathrm{Zr}$ compared to $\mathrm{Pd} / \mathrm{ZrO}_{2}$ before and after HTA was attributed to the poor crystallinity of $\mathrm{SiO}_{2} @ \mathrm{Zr}$ support. The poor crystallinity of $\mathrm{SiO}_{2} @ \mathrm{Zr}$ further contributes to the improved hydrothermal stability of $\mathrm{Pd} / \mathrm{SiO}_{2} @ \mathrm{Zr}$ under conditions of low temperature combustion of diesel (LTC-D). Overall, this study revealed the potential of developing high surface area $\mathrm{Pd} / \mathrm{SiO}_{2} @ \mathrm{Zr}$ 
catalysts with improved low temperature diesel oxidation performance and enhanced hydrothermal stability.

\section{References:}

[1] J. Lee, J.R. Theis, E.A. Kyriakidou, Vehicle emissions trapping materials: Successes, challenges, and the path forward, Appl. Catal. B 243 (2019) 397-414. https://doi.org/10.1016/j.apcatb.2018.10.069.

[2] A.P. Wong, E.A. Kyriakidou, T.J. Toops, J.R. Regalbuto, The catalytic behavior of precisely synthesized Pt-Pd bimetallic catalysts for use as diesel oxidation catalysts, Catal. Today 267 (2016) 145-156. https://doi.org/10.1016/j.cattod.2016.02.011.

[3] E. Kyriakidou, T.J. Toops, J.-S. Choi, M.J. Lance, J.E. Parks II, Exhaust treatment catalysts with enhanced hydrothermal stability and low-temperature activity, US Patents 10,42,137 B2 (October 1, 2019).

[4] M. Zammit, C.L. DiMaggio, C.H. Kim, C. Lambert, G.G. Muntean, C.H. Peden, J.E. Parks, K. Howden, Future automotive aftertreatment solutions: The $150 \mathrm{C}$ challenge workshop report (US Drive Workshop, 2012)

https://www.pnnl.gov/main/publications/external/technical_Reports/PNNL-22815.pdf.

[5] Y. Shin, Y. Jung, C.P. Cho, Y.D. Pyo, J. Jang, G. Kim, T.M. Kim, $\mathrm{NO}_{\mathrm{x}}$ abatement and $\mathrm{N}_{2} \mathrm{O}$ formation over urea-SCR systems with zeolite supported $\mathrm{Fe}$ and $\mathrm{Cu}$ catalysts in a nonroad diesel engine, Chem. Eng. J. 381 (2020) 122751. https://doi.org/10.1016/j.cej.2019.122751.

[6] B. Apicella, E. Mancaruso, C. Russo, A. Tregrossi, M.M. Oliano, A. Ciajolo, B.M. Vaglieco, Effect Of After-Treatment Systems On Particulate Matter Emissions In Diesel Engine Exhaust, Exp. Therm. Fluid Sci. (2020) 110107. https://doi.org/10.1016/j.expthermflusci.2020.110107. 
[7] A. Ko, Y. Woo, J. Jang, Y. Jung, Y. Pyo, H. Jo, O. Lim, Y.J. Lee, Complementary effects between $\mathrm{NO}$ oxidation of DPF and $\mathrm{NO}_{2}$ decomposition of SCR in light-duty diesel engine, J. Ind. Eng. Chem. 80 (2019) 160-170. https://doi.org/10.1016/j.jiec.2019.07.045.

[8] K.G. Rappé, C. DiMaggio, J.A. Pihl, J.R. Theis, S.H. Oh, G.B. Fisher, J. Parks, V.G. Easterling, M. Yang, M.L. Stewart, Aftertreatment Protocols for Catalyst Characterization and Performance Evaluation: Low-Temperature Oxidation, Storage, Three-Way, and $\mathrm{NH}_{3}-\mathrm{SCR}$ Catalyst Test Protocols, Emiss. Control Sci. Technol. 5(2) (2019) 183-214. https://doi.org/10.1007/s40825-019$\underline{00120-7 .}$

[9] S. Du, W. Tang, Y. Guo, A. Binder, E.A. Kyriakidou, T.J. Toops, S. Wang, Z. Ren, S. Hoang, P.-X. Gao, Understanding low temperature oxidation activity of nanoarray-based monolithic catalysts: from performance observation to structural and chemical insights, Emiss. Control Sci. Technol. 3(1) (2017) 18-36. https://doi.org/10.1007/s40825-016-0054-y.

[10] S. Hoang, Y. Guo, A.J. Binder, W. Tang, S. Wang, J.J. Liu, T.D. Huan, X. Lu, Y. Wang, Y. Ding, Activating low-temperature diesel oxidation by single-atom $\mathrm{Pt}$ on $\mathrm{TiO}_{2}$ nanowire array, Nat. Commun. 11(1) (2020) 1-10. https://doi.org/10.1038/s41467-020-14816-w.

[11] Y. Xie, E. Rodrigues, N. Furtado, A. Matynia, T. Arlt, P. Rodatz, P. Da Costa, Aging of commercial diesel oxidation catalysts: a preliminary structure/reactivity study, Top. Catal. 59(1012) (2016) 1039-1043. https://doi.org/10.1007/s11244-016-0586-y.

[12] D. Kunwar, C. Carrillo, H. Xiong, E. Peterson, A. DeLaRiva, A. Ghosh, G. Qi, M. Yang, M. Wiebenga, S. Oh, Investigating Anomalous Growth of Platinum Particles during Accelerated Aging of Diesel Oxidation Catalysts, Appl. Catal. B $266 \quad$ (2020) 118598. https://doi.org/10.1016/j.apcatb.2020.118598. 
[13] C. Carrillo, A. DeLaRiva, H. Xiong, E.J. Peterson, M.N. Spilde, D. Kunwar, R.S. Goeke, M. Wiebenga, S.H. Oh, G. Qi, S.R. Challa, A.K. Datye, Regenerative trapping: How Pd improves the durability of Pt diesel oxidation catalysts, Appl. Catal. B 218 (2017) 581-590. https://doi.org/10.1016/j.apcatb.2017.06.085.

[14] J. Liu, B. Qiao, Y. Song, Y. Huang, J.J. Liu, Hetero-epitaxially anchoring Au nanoparticles onto $\mathrm{ZnO}$ nanowires for $\mathrm{CO}$ oxidation, Chem. Comm. 51(83) (2015) 15332-15335. https://doi.org/10.1039/C5CC03353E.

[15] Y. Sun, W. Liu, M. Tian, L. Wang, Z. Wang, A Rational Design of the Sintering-Resistant $\mathrm{Au}-\mathrm{CeO}_{2}$ Nanoparticles Catalysts for $\mathrm{CO}$ Oxidation: The Influence of $\mathrm{H}_{2}$ Pretreatments, Materials 11(10) (2018) 1952. https://doi.org/10.3390/ma11101952.

[16] G.J. Kim, D.W. Kwon, S.C. Hong, Effect of Pt particle size and valence state on the performance of $\mathrm{Pt} / \mathrm{TiO}_{2}$ catalysts for $\mathrm{CO}$ oxidation at room temperature, J. Phys. Chem. C 120(32) (2016) 17996-18004. https://doi.org/10.1021/acs.jpcc.6b02945.

[17] Q. Guo, R. Joyner, An X-ray photoelectron spectroscopy study of the stability of $\mathrm{ZrO}_{2}$ films on Pd (110), Appl. Surf. Sci. 144 (1999) 375-379. https://doi.org/10.1016/S0169-4332(98)00827$\underline{7}$.

[18] J. Bitter, K. Seshan, J. Lercher, On the contribution of X-ray absorption spectroscopy to explore structure and activity relations of $\mathrm{Pt} / \mathrm{ZrO}_{2}$ catalysts for $\mathrm{CO}_{2} / \mathrm{CH}_{4}$ reforming, Top. Catal. 10(3-4) (2000) 295-305. https://doi.org/10.1023/A:1019149025242.

[19] C. Dall'Agnol, A. Gervasini, F. Morazzoni, F. Pinna, G. Strukul, L. Zanderighi, Hydrogenation of carbon monoxide: Evidence of a strong metal-support interaction in $\mathrm{RhZrO}_{2}$ catalysts, J. Catal. 96(1) (1985) 106-114. https://doi.org/10.1016/0021-9517(85)90364-1. 
[20] M.-Y. Kim, E.A. Kyriakidou, J.-S. Choi, T.J. Toops, A.J. Binder, C. Thomas, J.E. Parks II, V. Schwartz, J. Chen, D.K. Hensley, Enhancing low-temperature activity and durability of Pdbased diesel oxidation catalysts using $\mathrm{ZrO}_{2}$ supports, Appl. Catal. B 187 (2016) 181-194. https://doi.org/10.1016/j.apcatb.2016.01.023.

[21] D. Aguilar, L. Torres-Gonzalez, L. Torres-Martinez, T. Lopez, P. Quintana, A study of the crystallization of $\mathrm{ZrO}_{2}$ in the sol-gel system: $\mathrm{ZrO}_{2}-\mathrm{SiO}_{2}$, J. Solid State Chem. 158(2) (2001) 349357. https://doi.org/10.1006/jssc.2001.9126.

[22] G. Dingemans, A. Clark, J. Van Delft, M. Van De Sanden, W. Kessels, Er ${ }^{3+}$ and Si luminescence of atomic layer deposited Er-doped $\mathrm{Al}_{2} \mathrm{O}_{3}$ thin films on Si (100), J. Appl. Phys. 109(11) (2011) 113107. https://doi.org/10.1063/1.3595691.

[23] V. Nagarajan, K. Rao, Crystallization studies of $\mathrm{ZrO}_{2}-\mathrm{SiO}_{2}$ composite gels, J. Mater. Sci. 24(6) (1989) 2140-2146. https://doi.org/10.1007/BF02385434.

[24] T. Ono, M. Kagawa, Y. Syono, Ultrafine particles of the $\mathrm{ZrO}_{2}-\mathrm{SiO}_{2}$ system prepared by the spray-ICP technique, J. Mater. Sci. 20(7) (1985) 2483-2487. https://doi.org/10.1007/BF00556078. [25] C. Zhao, O. Richard, H. Bender, M. Caymax, S. De Gendt, M. Heyns, E. Young, G. Roebben, O. Van der Biest, S. Haukka, Miscibility of amorphous $\mathrm{ZrO}_{2}-\mathrm{Al}_{2} \mathrm{O}_{3}$ binary alloy, Appl. Phys. Lett. 80(13) (2002) 2374-2376. https://doi.org/10.1063/1.1459765.

[26] G. Balakrishnan, A. Wasy, H.S. Ho, P. Sudhakara, S. Bae, J. Song, Study of $\mathrm{Al}_{2} \mathrm{O}_{3} / \mathrm{ZrO}_{2}(5$ nm/20nm) Nanolaminate Composite, Compos. Res. 26(1) (2013) 60-65. https://doi.org/10.7234/kscm.2013.26.1.60.

[27] M.-Y. Kim, J.-S. Choi, T.J. Toops, E.-S. Jeong, S.-W. Han, V. Schwartz, J. Chen, Coating $\mathrm{SiO}_{2}$ support with $\mathrm{TiO}_{2}$ or $\mathrm{ZrO}_{2}$ and effects on structure and $\mathrm{CO}$ oxidation performance of $\mathrm{Pt}$ catalysts, Catalysts 3(1) (2013) 88-103. https://doi.org/10.3390/catal3010088. 
[28] D.P. Nolan, Fire Pump Arrangements at Industrial Facilities, third ed., Gulf Professional Publishing, Oxford, 2017.

[29] W. Stöber, A. Fink, E. Bohn, Controlled growth of monodisperse silica spheres in the micron size range, J. Colloid Interface Sci. 26(1) (1968) 62-69. https://doi.org/10.1016/0021$\underline{9797(68) 90272-5}$.

[30] C.-H. Liu, K. Giewont, T.J. Toops, E.A. Walker, C. Horvatits, E.A. Kyriakidou, Non-catalytic gas phase NO oxidation in the presence of decane, Fuel 286 (2021) 119388. https://doi.org/10.1016/j.fuel.2020.119388.

[31] S. Musić, N. Filipović-Vinceković, L. Sekovanić, Precipitation of amorphous $\mathrm{SiO}_{2}$ particles and their properties, Braz. J. Chem. Eng. 28(1) (2011) 89-94. https://doi.org/10.1590/S0104$\underline{66322011000100011 .}$

[32] S. Tada, S. Kayamori, T. Honma, H. Kamei, A. Nariyuki, K. Kon, T. Toyao, K.-i. Shimizu, S. Satokawa, Design of interfacial sites between $\mathrm{Cu}$ and amorphous $\mathrm{ZrO}_{2}$ dedicated to $\mathrm{CO}_{2}$-tomethanol hydrogenation, ACS Catalysis $\quad 8(9) \quad$ (2018) $\quad$ 7809-7819. https://pubs.acs.org/doi/abs/10.1021/acscatal.8b01396.

[33] F. Lu, J. Zhang, M. Huang, F. Namavar, R.C. Ewing, J. Lian, Phase transformation of nanosized $\mathrm{ZrO} 2$ upon thermal annealing and intense radiation, J. Phys. Chem. C 115(15) (2011) 7193-7201. https://doi.org/10.1021/jp109558s.

[34] K.S. Sing, Reporting physisorption data for gas/solid systems with special reference to the determination of surface area and porosity (Recommendations 1984), Pure Appl. Chem. 57(4) (1985) 603-619.

[35] R.G. Bergman, C-H activation, Nature 446(7134) (2007) 391-393. https://doi.org/10.1038/446391a. 
[36] S.S. Kum, B.Y. Jo, S.H. Moon, Performance of Pd-promoted Mo-V-Te-Nb-O catalysts in the partial oxidation of propane to acrylic acid, Appl. Catal, A 365(1) (2009) 79-87. https://doi.org/10.1016/j.apcata.2009.05.056.

[37] P. Piqueras, A. García, J. Monsalve-Serrano, M.J. Ruiz, Performance of a diesel oxidation catalyst under diesel-gasoline reactivity controlled compression ignition combustion conditions, Energy Convers. Manag. 196 (2019) 18-31. https://doi.org/10.1016/j.enconman.2019.05.111. [38] R. Burch, J. Breen, F. Meunier, A review of the selective reduction of NOx with hydrocarbons under lean-burn conditions with non-zeolitic oxide and platinum group metal catalysts, Appl. Catal. B 39(4) (2002) 283-303. https://doi.org/10.1016/S0926-3373(02)00118-2.

[39] X. Auvray, L. Olsson, Stability and activity of Pd-, Pt-and Pd-Pt catalysts supported on alumina for NO oxidation, Appl. Catal. B 168 (2015) 342-352. https://doi.org/10.1016/j.apcatb.2014.12.035.

[40] T. Zhang, J. Ge, Y. Hu, Q. Zhang, S. Aloni, Y. Yin, Formation of hollow silica colloids through a spontaneous dissolution-regrowth process, Angew. Chem. 120(31) (2008) 5890-5895. https://doi.org/10.1002/ange.200800927.

[41] N. Hassan, A. Jalil, N. Khusnun, M. Ali, S. Haron, Role of reduced graphene oxide in improving interfacial charge transfer of hybridized $\mathrm{rGO}$ /silica/zirconia for enhanced Bisphenol A photodegradation, J. Alloys Compd. $789 \quad$ (2019) 221-230. https://doi.org/10.1016/j.jallcom.2019.03.105. [42] P.M. Arnal, C. Weidenthaler, F. Schüth, Highly monodisperse zirconia-coated silica spheres and zirconia/silica hollow spheres with remarkable textural properties, Chem. Mater. 18(11) (2006) 2733-2739. https://doi.org/10.1021/cm052580a. 
[43] S. Kongwudthiti, P. Praserthdam, W. Tanakulrungsank, M. Inoue, The influence of Si-O-Zr bonds on the crystal-growth inhibition of zirconia prepared by the glycothermal method, J. Mater. Process. Technol. 136(1-3) (2003) 186-189. https://doi.org/10.1016/S0924-0136(03)00157-2. [44] H.Y. Law, J. Blanchard, X. Carrier, C. Thomas, NOx-TPD as a Tool to Estimate the Accessible Zirconia Surface of $\mathrm{ZrO}_{2}$-Containing Materials, J. Phys. Chem. C 114(21) (2010) 97319738. https://doi.org/10.1021/jp9089535.

[45] C. Thomas, Should W Surface Density of $\mathrm{WO}_{\mathrm{x}}-\mathrm{ZrO}_{2}$ Catalysts Be Calculated With Respect To the Specific Surface Area of the Sample or That of $\mathrm{ZrO}_{2}$ Only?, J. Phys. Chem. C 115(5) (2011) 2253-2256. https://doi.org/10.1021/jp110497e.

[46] M. Ogura, R. Guillet-Nicolas, D. Brouri, S. Casale, J. Blanchard, K.A. Cychosz, M. Thommes, C. Thomas, Insights into the accessibility of $\mathrm{Zr}$ in $\mathrm{Zr} / \mathrm{SBA}-15$ mesoporous silica supports with increasing $\mathrm{Zr}$ loadings, Micropor. Mesopor. Mat. 225 (2016) 440-449. https://doi.org/10.1016/j.micromeso.2016.01.026. 
Table 1. BET surface areas and $\mathrm{BJH}$ pore volumes of $\mathrm{SiO}_{2}$ core, $\mathrm{SiO}_{2} @ \mathrm{Zr}$, and (fresh, HTA) 1 wt.\%Pd/SiOn @Zr.

\begin{tabular}{|c|c|c|}
\hline & $\begin{array}{c}\text { BET surface area } \\
\left(\mathrm{m}^{2} / \mathrm{g}\right)\end{array}$ & $\begin{array}{c}\text { BJH pore volume } \\
\left(\mathrm{cm}^{3} / \mathrm{g}\right)\end{array}$ \\
\hline Fresh $\mathrm{SiO}_{2}$ & 2.3 & 0.009 \\
\hline Fresh $\mathrm{SiO}_{2} @ \mathrm{Zr}$ & 226.7 & 0.170 \\
\hline Fresh1 wt.\%Pd/SiO & 207.2 & 0.089 \\
\hline HTA 1 wt.\% & 103.9 & \\
\hline
\end{tabular}




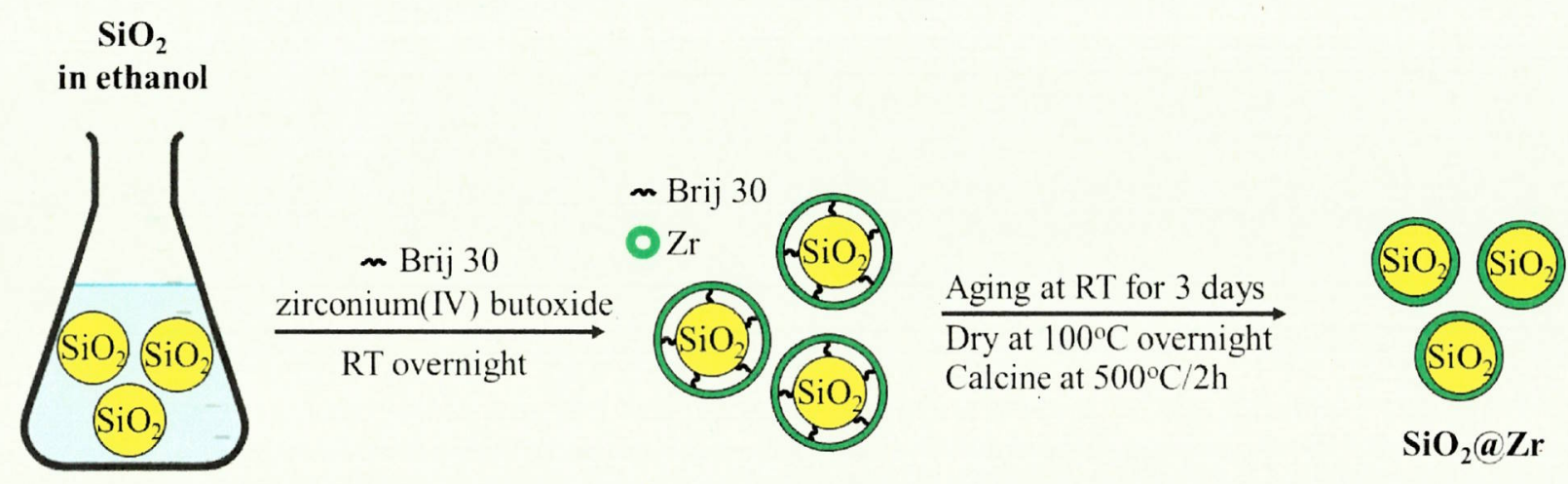

Fig. 1. Synthesis of $\mathrm{SiO}_{2} @ \mathrm{Zr}$ core@shell support using a hard template method. 

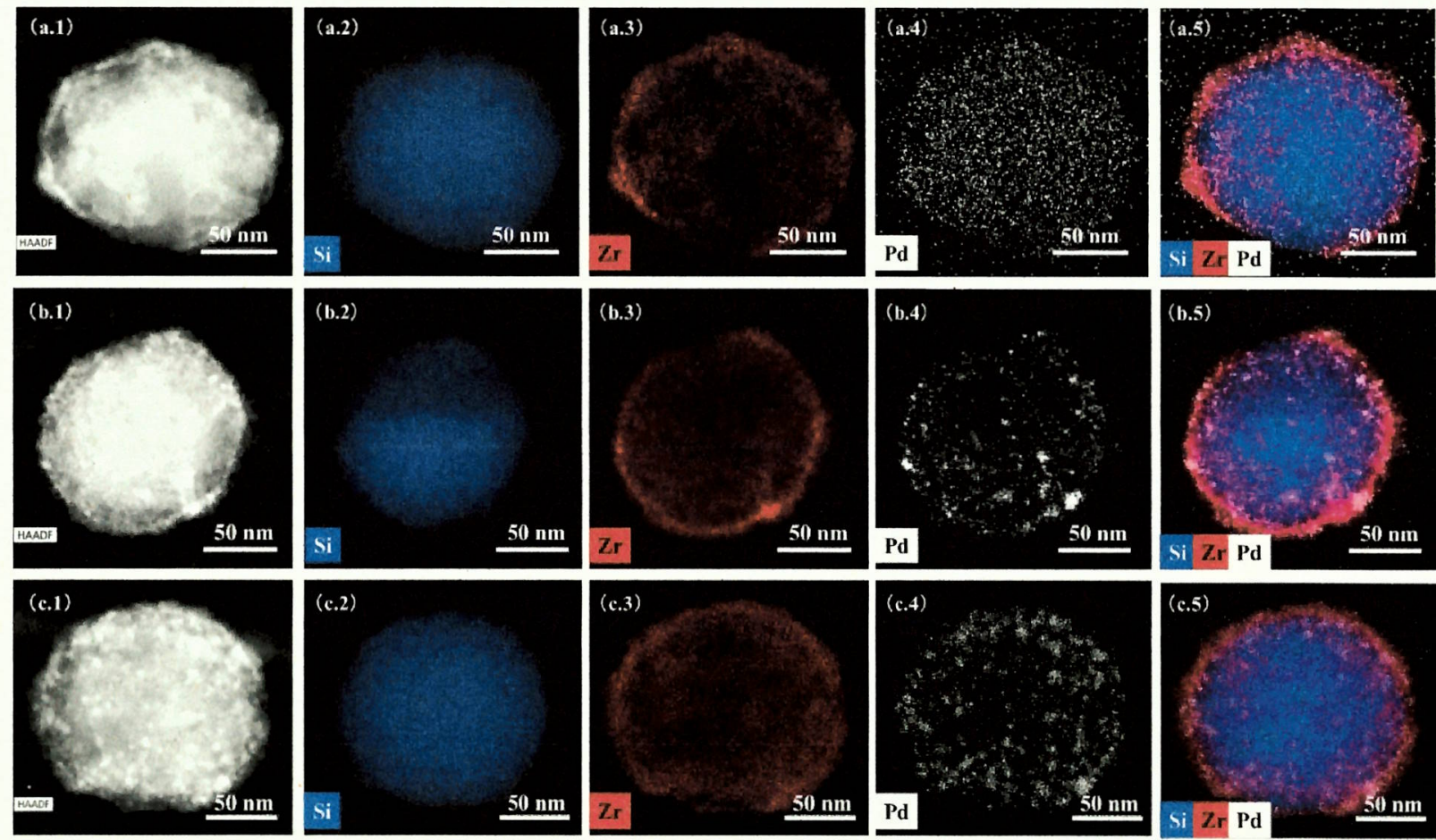

Fig. 2. HAADF-STEM images and EDS elemental maps of fresh (a.1-5) 1 wt.\% Pd/SiO 2 @ Zr, (b.1-5) 2 wt.\%Pd/SiO $@$ @Zr, and (c.1-5) 4 wt.\%Pd/ $/ \mathrm{SiO}_{2} @ Z$ Zr catalysts. 

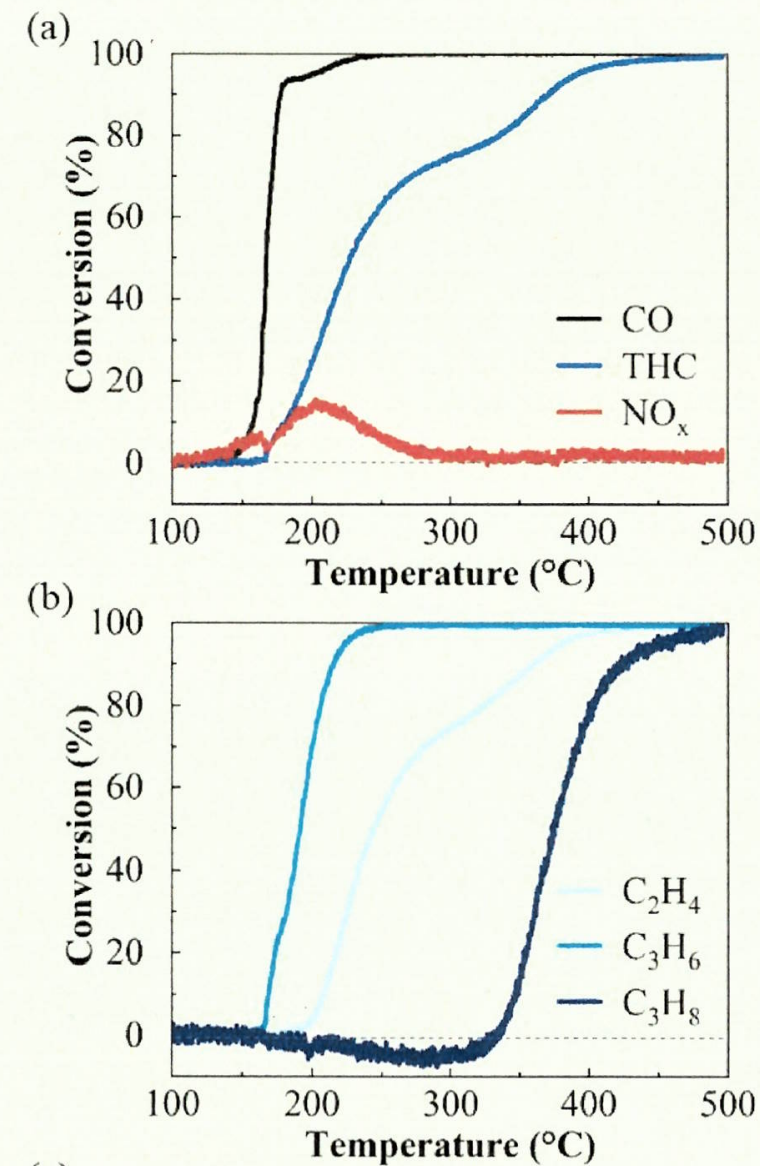

(c)

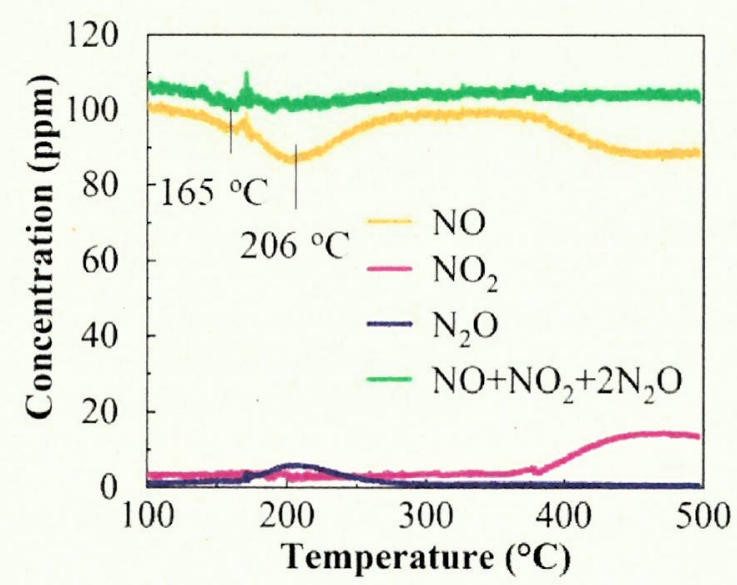

Fig. 3. (a) $\mathrm{CO}, \mathrm{THC}, \mathrm{NO}_{\mathrm{x}}$, (b) $\mathrm{C}_{2} \mathrm{H}_{4}, \mathrm{C}_{3} \mathrm{H}_{6}, \mathrm{C}_{3} \mathrm{H}_{8}$ conversions and (c) $\mathrm{NO}, \mathrm{NO}_{2}, \mathrm{~N}_{2} \mathrm{O}$ concentrations and their total concentration $\left(=[\mathrm{NO}]+\left[\mathrm{NO}_{2}\right]+2\left[\mathrm{~N}_{2} \mathrm{O}\right]\right)$ as a function of temperature of degreened 1 wt.\% Pd/SiO $2 @ \mathrm{Zr}$. 

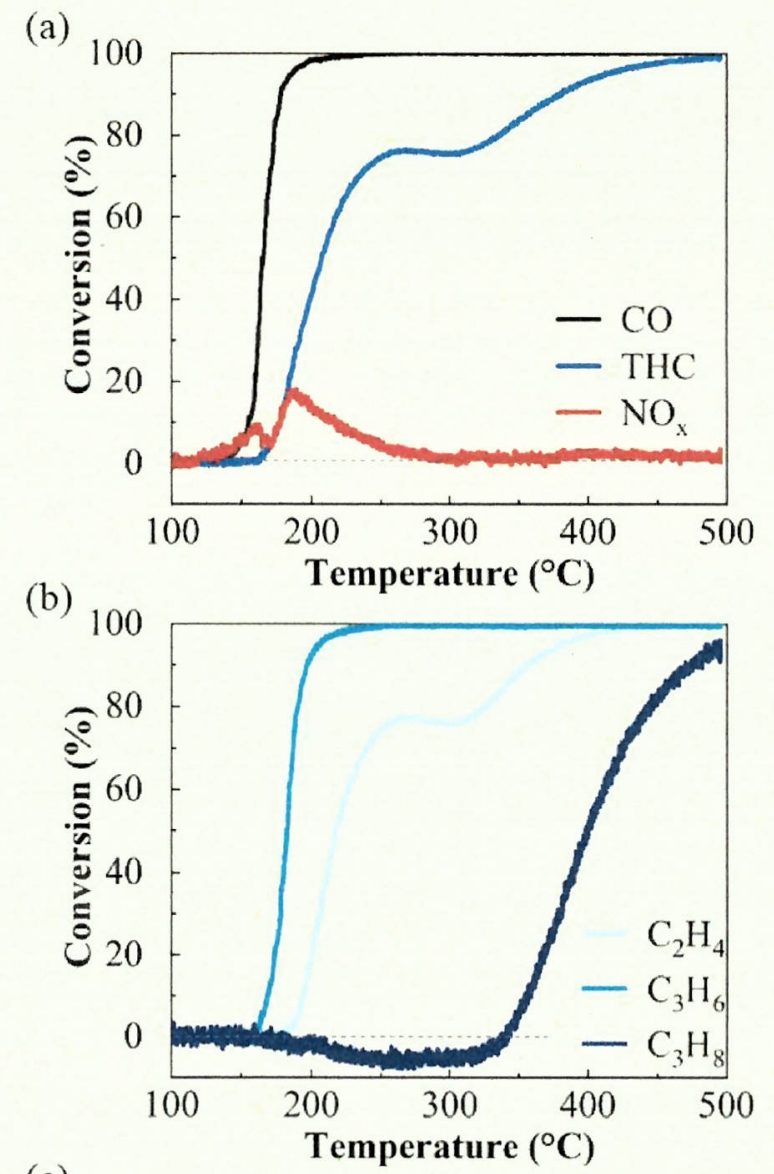

(c)

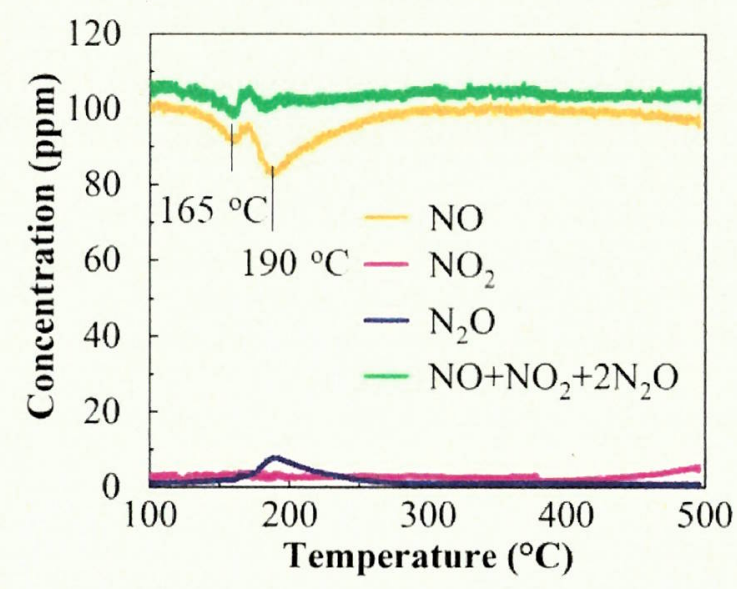

Fig. 4. (a) CO, THC, $\mathrm{NO}_{x}$, (b) $\mathrm{C}_{2} \mathrm{H}_{4}, \mathrm{C}_{3} \mathrm{H}_{6}, \mathrm{C}_{3} \mathrm{H}_{8}$ conversions and (c) $\mathrm{NO}, \mathrm{NO}_{2}, \mathrm{~N}_{2} \mathrm{O}$ concentrations and their total concentration $\left(=[\mathrm{NO}]+\left[\mathrm{NO}_{2}\right]+2\left[\mathrm{~N}_{2} \mathrm{O}\right]\right)$ as a function of temperature of hydrothermally aged 1 wt.\% Pd/SiO $2 @ Z r$. 


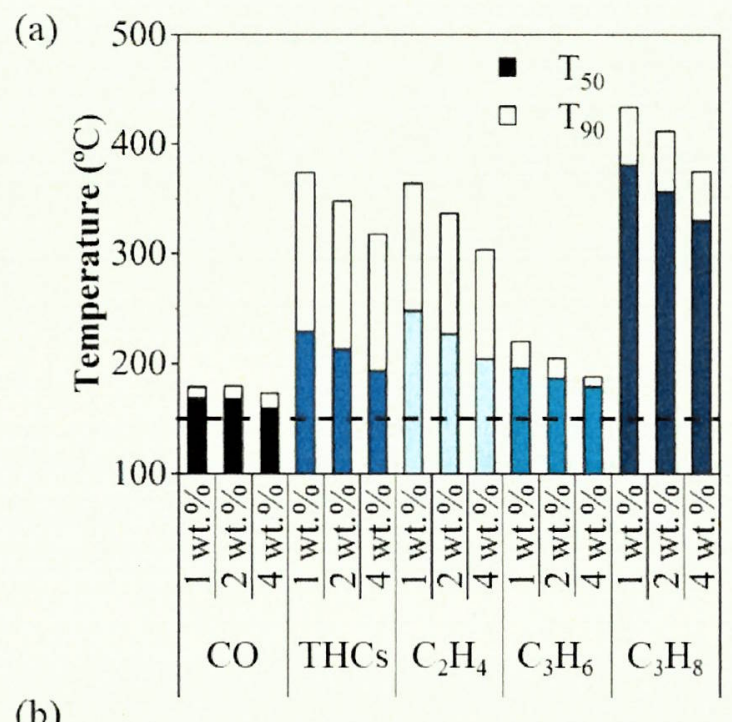

(b)

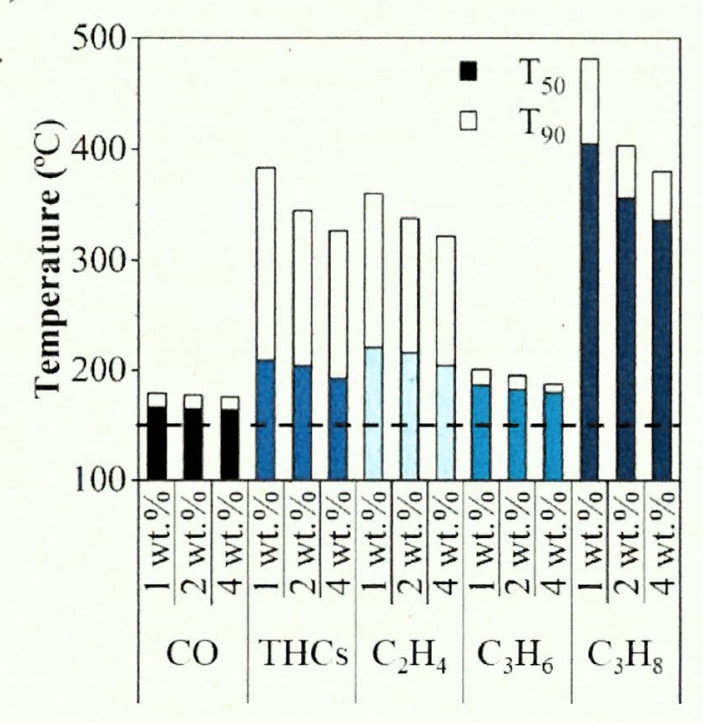

Fig. 5. Comparison of $\mathrm{T}_{50,90}$ 's of $\mathrm{CO}$, THCs, $\mathrm{C}_{2} \mathrm{H}_{4}, \mathrm{C}_{3} \mathrm{H}_{6}, \mathrm{C}_{3} \mathrm{H}_{8}$ over (a) degreened and (b) hydrothermally aged 1,2,4 wt.\% Pd/SiO $2 @ Z r$ catalysts. The horizontal dashed line denotes the $150{ }^{\circ} \mathrm{C}$ target temperature for achieving $90 \%$ conversion. 


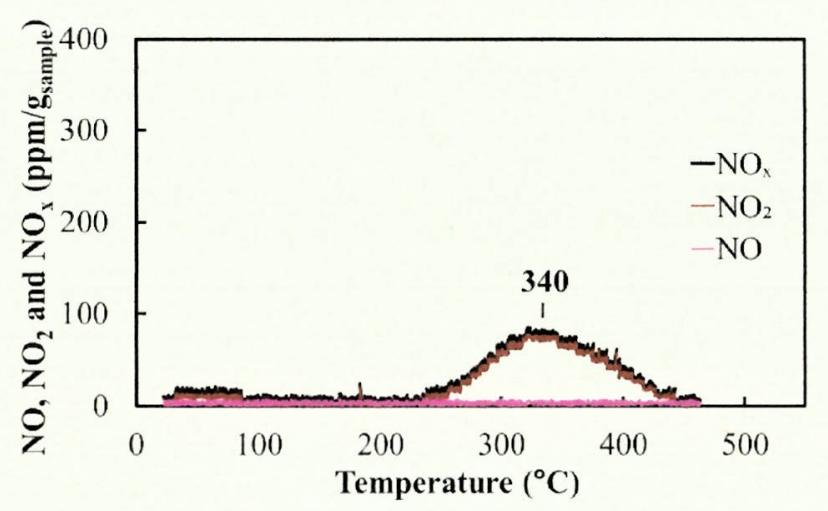

Fig. 6. $\mathrm{NO}_{\mathrm{x}}-\mathrm{TPD}$ profiles over fresh $\mathrm{SiO}_{2} @ \mathrm{Zr}$. 
Supplementary material

\section{Hydrothermally Stable Pd/SiO $@$ @r Core@Shell Catalysts for Diesel}

\section{Oxidation Applications}

ChihHan Liu ${ }^{\mathrm{a},+}$, Junjie Chen ${ }^{\mathrm{a},+}$, Todd J. Toops ${ }^{\mathrm{b}}$, Jae-Soon Choi ${ }^{\mathrm{b}, 1}$, Cyril Thomas ${ }^{\mathrm{c}}$, Michael J. Lance $^{\mathrm{b}}$, and Eleni A. Kyriakidou ${ }^{\mathrm{a}, *}$

${ }^{a}$ Department of Chemical and Biological Engineering, University at Buffalo, The State University of New York, Buffalo, NY 14260, USA

${ }^{b}$ Oak Ridge National Laboratory, Oak Ridge, TN 37831, USA

'Sorbonne Université, CNRS, Laboratoire de Réactivité de Surface (LRS), 4 Place Jussieu, F-75252 Paris, France

${ }^{+}$These authors contributed equally to this work

${ }^{1}$ Present address: Catalyst Development Center, Basic Materials and Chemicals R\&D, LG Chem, Daejeon, Korea.

*Corresponding author at: elenikyr@buffalo.edu (E.A. Kyriakidou)

This manuscript has been authored by UT-Battelle, LLC under Contract No. DE-AC0500OR22725 with the U.S. Department of Energy. The United States Government retains and the publisher, by accepting the article for publication, acknowledges that the United States Government retains a non-exclusive, paid-up, irrevocable, world-wide license to publish or reproduce the published form of this manuscript, or allow others to do so, for United States Government purposes. The Department of Energy will provide public access to these results of federally sponsored research in accordance with the DOE Public Access Plan (http://energy.gov/downloads/doe-public-access-plan). 
Table of Contents

2. Reagents and materials 2

3. Characterizations 3

4. Table S1 4

5. Figure S1 5

6. Figure S2 6

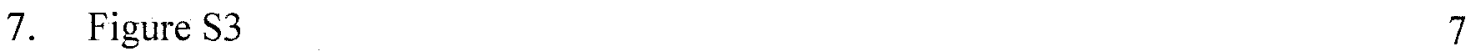

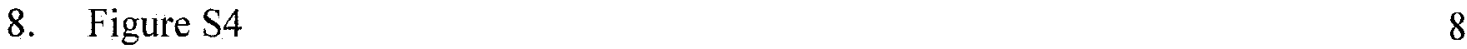

9. Figure S5 9

$\begin{array}{ll}\text { 10. Video } \mathrm{S} 1 & 10\end{array}$

11. References 11 


\section{Reagents and materials}

Zirconium(IV) butoxide solution $\left(\mathrm{Zr}(\mathrm{BuO})_{4}\right)$ (80 wt.\% in 1-butanol, Sigma-Aldrich), tetraethyl orthosilicate (TEOS) (98\% purity, Strem), anhydrous ethyl alcohol (200 proof, Decon), ammonium hydroxide $\left(\mathrm{NH}_{4} \mathrm{OH}, 28-30\right.$ wt.\% solution of $\mathrm{NH}_{3}$ in water, Sigma-Aldrich), nitric acid (65 wt.\%, Fisher) and tetraamminepalladium nitrate $\left(\mathrm{Pd}\left(\mathrm{NH}_{3}\right)_{4}\left(\mathrm{NO}_{3}\right)_{2}\right)\left(10 \%\right.$ in $\mathrm{H}_{2} \mathrm{O}$, SigmaAldrich), zirconium silicate (98\%, ACROS) were used as received. Brij30 (ACROS) was diluted with DI water to a 3.76 wt.\% Brij30 solution prior to usage. Nitric acid was diluted with DI water to $0.1 \mathrm{M}$ prior to usage. DI water purified to $18.2 \mathrm{M} \Omega \bullet \mathrm{cm}$ (Milli-Q grade) was used for all reported synthesis.

\section{Characterizations}

HAADF-STEM images and EDS elemental maps of Pd/SiO $@$ $\mathrm{Zr}$ catalysts were obtained with a FEI Talos F200X STEM. The catalysts were first dispersed in isopropyl alcohol under ultrasonication for 15 minutes. One drop of the solution was added onto carbon-coated copper TEM grids followed by drying in air at ambient temperature.

The BET surface areas and BJH pore volumes of the studied samples were determined by $\mathrm{N}_{2}$ physisorption with a Micromeritics Tri-Star II surface area and porosity analyzer. Before the measurement, all the samples were degassed at $150^{\circ} \mathrm{C}$ for $2 \mathrm{~h}$.

XRD was conducted in a Rigaku Ultima IV using a $\mathrm{Cu}-\mathrm{K} \alpha$ X-ray source (wavelength: $0.15406 \mathrm{~nm}$ ) operating at $40 \mathrm{kV}, 44 \mathrm{~mA}$. XRD patterns were collected in a $2 \theta$ range of $5-85^{\circ}$, with a scan rate of $2 \%$ min.

Fourier transform infrared (FT-IR) spectra of $\mathrm{SiO}_{2}$ spheres and $\mathrm{SiO}_{2} @ \mathrm{Zr}$ were collected between $400-4000 \mathrm{~cm}^{-1}$ with a Bruker Vertex 70 FTIR spectrophotometer. 
$\mathrm{NO}_{\mathrm{x}}$-TPD experiments were conducted following the procedure reported previously [1]. The catalysts $(\sim 500 \mathrm{mg})$ were first loaded in a U-shaped quartz reactor (I.D. $=15 \mathrm{~mm})$ and pretreated at $500{ }^{\circ} \mathrm{C} / 2 \mathrm{~h}$ with $100 \mathrm{sccm}(100 \mathrm{~mL} / \mathrm{min}, \mathrm{STP}) 20 \% \mathrm{O}_{2} / \mathrm{He}$. After cooling down to room temperature, the samples were exposed to the adsorption mixture $\left(400 \mathrm{ppm} \mathrm{NO}_{\mathrm{x}}\right.$ and $8 \%$ $\left.\mathrm{O}_{2} / \mathrm{He}\right)$ for $\sim 200 \mathrm{~min}$. The samples were then purged with $8 \% \mathrm{O}_{2} / \mathrm{He}(230 \mathrm{sccm})$ to remove gas phase $\mathrm{NO}_{\mathrm{x}}$ until negligible $\mathrm{NO}$ and $\mathrm{NO}_{2}$ were detected at the reactor outlet, followed by heating up to $560{ }^{\circ} \mathrm{C}\left(3{ }^{\circ} \mathrm{C} / \mathrm{min}\right)$ to perform the $\mathrm{NO}_{\mathrm{x}}-\mathrm{TPD}$ experiments. The $\mathrm{NO}$ and $\mathrm{NO}_{2}$ concentrations were recorded by a chemiluminescence $\mathrm{NO}_{\mathrm{x}}$ analyzer $(42 \mathrm{C}-\mathrm{HT}$, Thermo Environmental Instruments). A correction for the weight loss due to dehydration of the samples was conducted for the $\mathrm{NO}_{\mathrm{x}}$-TPD profiles. 
Table S1. Simulated exhaust for low temperature combustion of diesel (LTC-D) based on the low temperature oxidation protocol by U.S. Drive [2], balance Ar.

\begin{tabular}{|c|c|}
\hline Components & Concentration \\
\hline $\mathrm{O}_{2}$ & $12 \%$ \\
\hline $\mathrm{H}_{2} \mathrm{O}$ & $6 \%$ \\
\hline $\mathrm{CO}_{2}$ & $400 \mathrm{ppm}$ \\
\hline $\mathrm{H}_{2}$ & $2000 \mathrm{ppm}$ \\
\hline $\mathrm{CO}$ & $100 \mathrm{ppm}$ \\
\hline $\mathrm{NO}$ & $3000 \mathrm{ppm}$ \\
\hline \multicolumn{2}{|c|}{$\mathrm{Hydrocarbon}-\mathrm{on}_{1}$ basis } \\
\hline $\mathrm{Total} \mathrm{HCs} \mathrm{HC}$ \\
\hline $\mathrm{C}_{2} \mathrm{H}_{4}$ & $1667 \mathrm{ppm}$ \\
\hline $\mathrm{C}_{3} \mathrm{H}_{6}$ & $1000 \mathrm{ppm}$ \\
\hline $\mathrm{C}_{3} \mathrm{H}_{8}$ & $333 \mathrm{ppm}$ \\
\hline
\end{tabular}




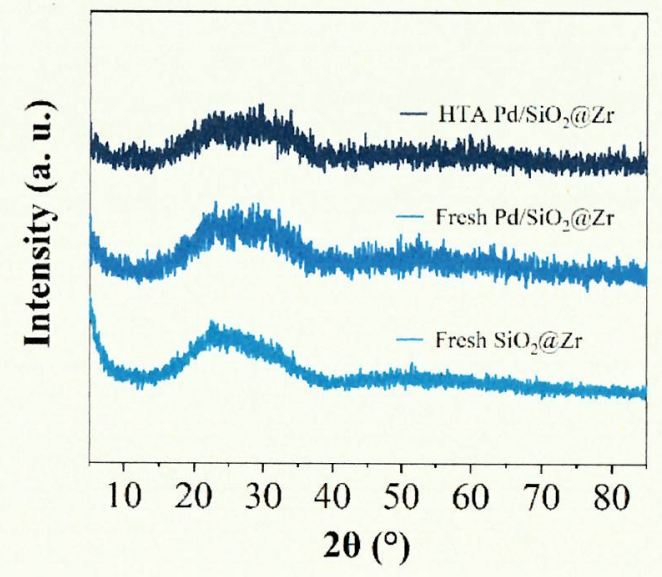

Fig. S1. XRD patterns of fresh $\mathrm{SiO}_{2} @ \mathrm{Zr}$, fresh and HTA 1 wt.\% Pd/SiO $/ \mathrm{Zr}$. 


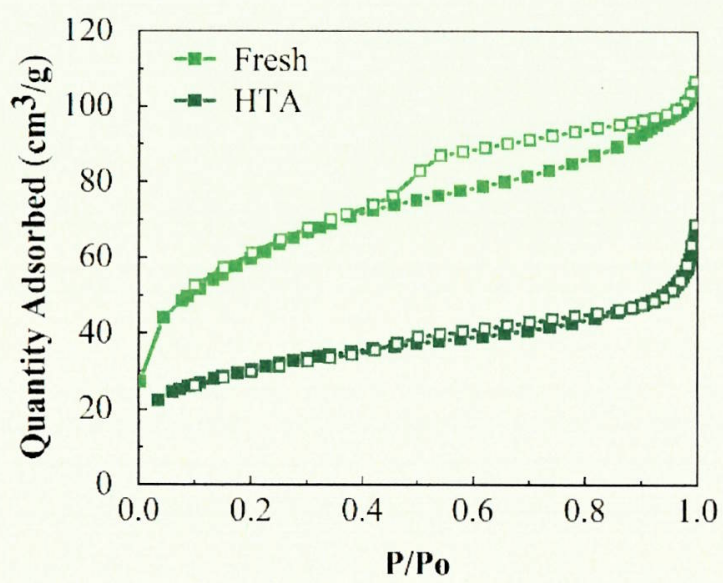

Fig. S2. $\mathrm{N}_{2}$ adsorption (solid) - desorption (open) isotherms of fresh and HTA 1 wt.\% $\mathrm{Pd} / \mathrm{SiO}_{2} @ \mathrm{Zr}$. 

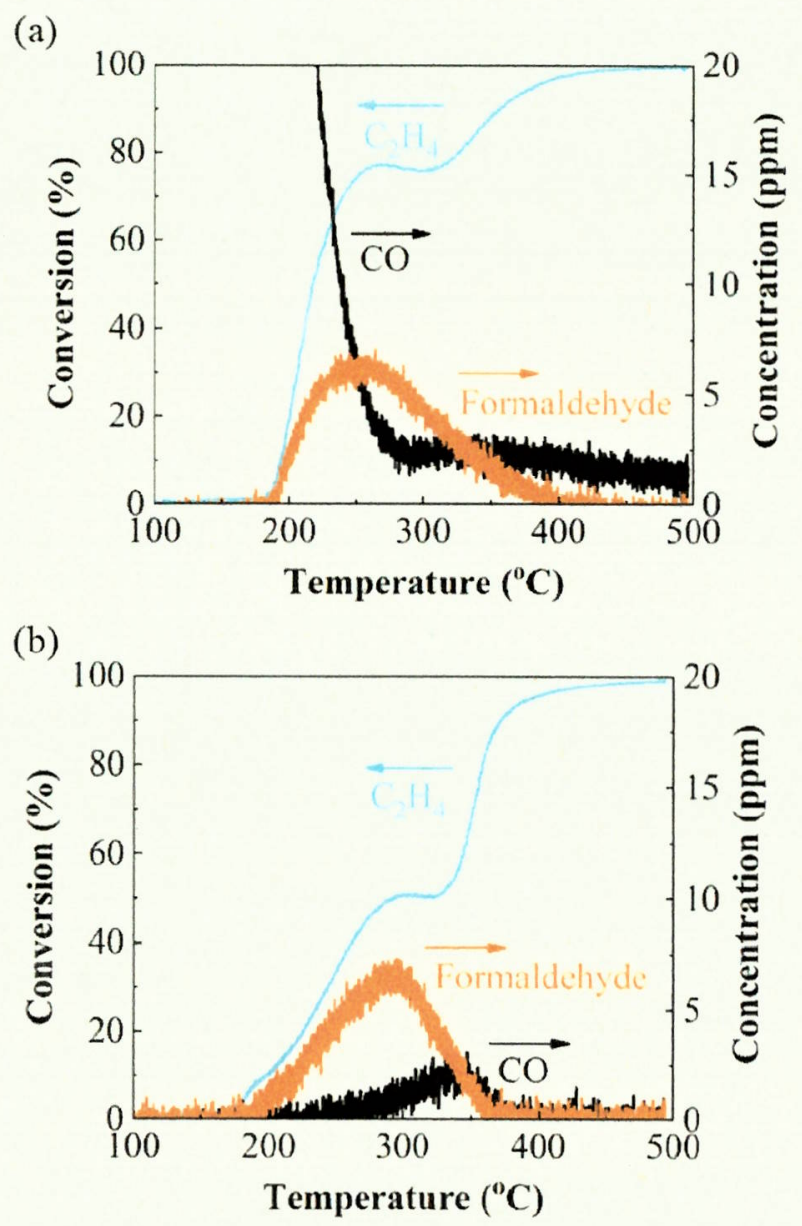

Fig. S3. $\mathrm{C}_{2} \mathrm{H}_{4}$ conversion (left $\mathrm{y}$-axis) and $\mathrm{CO}$, formaldehyde concentrations (right $\mathrm{y}$-axis) over hydrothermally aged 1 wt.\% Pd/SiO $/ 2 \mathrm{Zr}$ under reactor feed containing (a) 6\% $\mathrm{CO}_{2}, 12 \% \mathrm{O}_{2}, 6 \%$ $\mathrm{H}_{2} \mathrm{O}, 400 \mathrm{ppm} \mathrm{H}, 2000$ ppm CO, 100 ppm NO, 1667 ppm $\mathrm{C}_{2} \mathrm{H}_{4}, 1000$ ppm $\mathrm{C}_{3} \mathrm{H}_{6}, 333 \mathrm{ppm} \mathrm{C}_{3} \mathrm{H}_{8}$ and (b) $6 \% \mathrm{CO}_{2}, 12 \% \mathrm{O}_{2}, 6 \% \mathrm{H}_{2} \mathrm{O}, 400 \mathrm{ppm} \mathrm{H}_{2}, 1667 \mathrm{ppm} \mathrm{C}_{2} \mathrm{H}_{4}$; $\mathrm{HCs}$ in $\mathrm{C}_{1}$ basis. The slow lightoff profile of $\mathrm{C}_{2} \mathrm{H}_{4}$ in Fig. S3b compared to Fig. S3a can be attributed to the decreased exothermic effect when $\mathrm{C}_{3} \mathrm{H}_{6}, \mathrm{C}_{3} \mathrm{H}_{8}$, and $\mathrm{CO}$ were removed from the reactor feed (data not shown). 


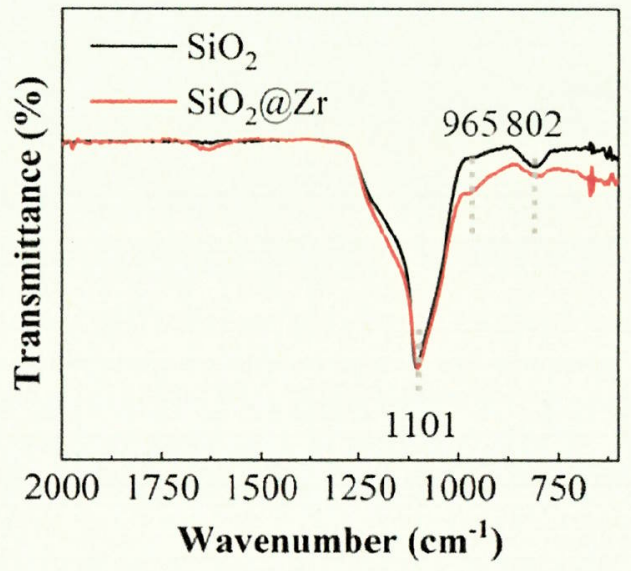

Fig. S4. FT-IR spectra of $\mathrm{SiO}_{2}$ spheres and $\mathrm{SiO}_{2} @ \mathrm{Zr}$ support. 


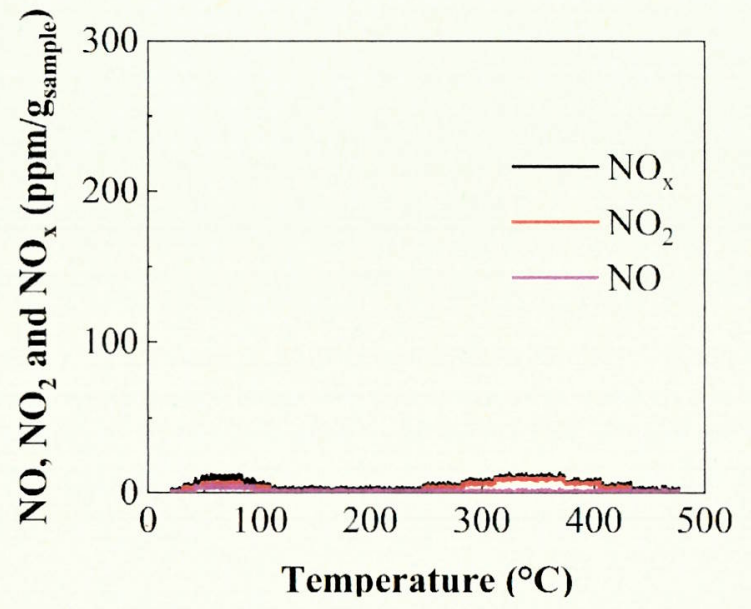

Fig. S5. $\mathrm{NO}_{x}-\mathrm{TPD}$ profiles over fresh $\mathrm{ZrSiO}_{4}$. 
Video. S1.3D tomography video of 1 wt.\% $\mathrm{Pd} / \mathrm{SiO}_{2} @ \mathrm{Zr}$. 


\section{References:}

[1] H.Y. Law, J. Blanchard, X. Carrier, C. Thomas, $\mathrm{NO}_{\mathrm{x}}-\mathrm{TPD}$ as a Tool to Estimate the Accessible Zirconia Surface of $\mathrm{ZrO}_{2}$-Containing Materials, J. Phys. Chem. C 114(21) (2010) 9731-9738. https://doi.org/https://doi.org/10.1021/jp9089535.

[2] K.G. Rappé, C. DiMaggio, J.A. Pihl, J.R. Theis, S.H. Oh, G.B. Fisher, J. Parks, V.G. Easterling, M. Yang, M.L. Stewart, Aftertreatment Protocols for Catalyst Characterization and Performance Evaluation: Low-Temperature Oxidation, Storage, Three-Way, and $\mathrm{NH}_{3}-\mathrm{SCR}$ Catalyst Test Protocols, Emiss. Control Sci. Technol. 5(2) (2019) 183-214. https://doi.org/https://doi.org/10.1007/s40825-019-00120-7. 